Vegetalika. 2020. 9(2): 425-436

\title{
Pengurangan Penggunaan Pupuk Urea Melalui Pemanfaatan Tanaman Turi Mini (Sesbania rostrata) pada Budidaya Jagung Manis
}

\section{Reducing of Urea Usage Through the Utilization Of Turi Mini Plants} (Sesbania rostrata) in the Sweet Corn Cultivation

\author{
Iqbal Effendy ${ }^{1 *}$, Paiman ${ }^{2)}$, Neni Marlina ${ }^{3)}$ \\ 1)Program Studi Agroteknologi, Fakultas Pertanian, Universitas Musi Rawas \\ Jalan Pembangunan Kompleks Perkantoran Pemkab Mura, Lubuklinggau, Sumatera \\ Selatan, Indonesia. \\ 2)Program Studi Agroteknologi, Fakultas Pertanian, Universitas PGRI Yogyakarta \\ Jalan PGRI I Sonosewu No. 117 Yogyakarta, Indonesia. \\ 3)Program Studi Agroteknologi, Fakultas Pertanian, Universitas Palembang \\ Jalan Darmapala Palembang, Sumatera Selatan, Indonesia. \\ ${ }^{*}$ Penulis untuk koresponden Email : iqbaleffendyunmura@gmail.com
}

\begin{abstract}
The use of inorganic fertilizer in agriculture as well as on sweet corn cultivation is quite high. Inorganic fertilizer recommended for sweet corn is $35 \mathrm{~kg}_{\text {urea ha-1, }} 150$ $\mathrm{kg} \mathrm{TSP} \mathrm{ha-1}$ and $150 \mathrm{~kg} \mathrm{KCl} \mathrm{ha}^{-1}$. Besides high prices, its difficult to find when needed. To overcome this, an experiment was carried out by utilizing TM plants for reducing urea input. This research was carried out in Air Kuti Village, South Lubuklinggau District I, Lubuklinggau City, South Sumatera Province with an altitude of 110 meters above sea level (ASL), from April to June 2017. The experiment was arranged out in a randomized completely block design (RCBD) factorial $4 \times 3$ and repeated three times. The first factor was treatment combination of inorganic $\mathbf{N}$ fertilizer (urea) and TM plants consisted 4 kinds i.e: $75 \%$ urea and 1 TM plant, $50 \%$ urea and 2 TM plants, $25 \%$ urea and 3 TM plants, and $0 \%$ urea and 4 TM plants. The second factor was a frequency of urea application consisted of 3 levels i.e: 1-time application 15 days after planted (15 DAP), 2 times application (15 and 30 DAP), and 3 times application (15, 30 and 45 DAP). The results showed that application of urea fertilizer dosage of $25 \%$ recommended $\left(108,75 \mathrm{~kg}_{\text {urea ha-1 }}{ }^{-1}\right)$ combinated with 3 stem of TM plants produced the best growth and yield of sweet corn. The frequency of urea application 3 times produced the best growth and yield of sweet corn.
\end{abstract}

Keywords: Sweet corn, Turi Mini, urea, polibag

\section{INTISARI}

Penggunaan pupuk anorganik pada budidaya jagung manis tergolong cukup tinggi. Rekomendasi dosis pupuk untuk tanaman jagung manis yaitu: $435 \mathrm{~kg}$ urea 


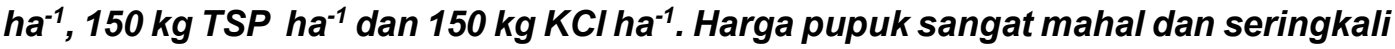
sulit didapatkan saat dibutuhkan petani. Untuk mengatasi hal tersebut, telah dilakukan percobaan dengan memanfaatkan tanaman turi mini (TM) untuk mengurangi asupan urea anorganik. Penelitian ini dilaksanakan di Kelurahan Air Kuti, Kecamatan Lubuklinggau Selatan I, Kota Lubuklinggau, Provinsi Sumatera Selatan dengan ketinggian tempat 110 meter di atas permukaan laut (DPL), dan dilakukan pada bulan April-Juni 2017. Penelitian disusun dalam rancangan acak lengkap kelompok (RALK) faktorial $4 \times 3$ dan diulang 3 kali. Faktor pertama yaitu kombinasi perlakuan pupuk $\mathbf{N}$ anorganik (urea) dan TM terdiri atas 4 macam, yaitu: $75 \%$ urea anjuran dan 1 batang TM, 50\% urea anjuran dan 2 batang TM, 25\% urea anjuran dan 3 batang TM, dan $0 \%$ urea anjuran dan 4 batang TM. Faktor kedua yaitu perlakuan frekuensi aplikasi pupuk urea pada tanaman jagung manis yang terdiri atas 3 macam umur, yaitu: 1 kali aplikasi pada 15 hari setelah tanam (15 HST), 2 kali aplikasi (15 dan 30 HST), dan 3 kali aplikasi (15, 30, dan 45 HST). Hasil penelitian menunjukkan pemberian pupuk urea $25 \%$ dari dosis anjuran (435 kg urea ha-1) yang dikombinasikan dengan 3 batang tanaman TM menghasilkan pertumbuhan dan hasil tanaman jagung manis yang terbaik. Perlakuan frekuensi aplikasi urea sebanyak 3 kali menghasilkan pertumbuhan dan hasil tanaman jagung manis yang terbaik.

Kata kunci: Jagung manis, turi mini dan urea

\section{PENDAHULUAN}

Jagung manis (Zea mays var. Saccharata Sturt) mulai dikembangkan di Indonesia pada awal tahun 1980an, secara komersial lebih menguntungkan karena umurnya yang relatif lebih singkat dari jagung biasa hingga dapat menekan biaya produksi serta meningkatkan pendapatan petani (Fahrurrozi et al., 2016). Jagung manis semakin digemari untuk dikonsumsi karena memiliki rasa yang lebih manis, aroma lebih harum, dan kandungan gizi yang lebih tinggi dibandingkan dengan jagung biasa, serta aman dikonsumsi bagi penderita diabetes karena mengandung gula sukrosa dan rendah lemak. Jagung manis hampir sama dengan jagung biasa, perbedaannya yang mencolok adalah kandungan zat gula yang lebih tinggi 5-6\% dibanding dengan jagung biasa sekitar 2-3\% dan umur panennya rata-rata 60-70 hari setelah tanam (Jurnaha et al., 2017).

Keistimewaan lain yang dimiliki jagung manis adalah biji, dari butiran jagung manis lebih khas, tidak lembek dan memiliki serat yang tidak terlalu liat, megandung gizi serta memiliki nilai ekonomis (Nuryadin et al., 2016). Hal ini menyebabkan jagung manis banyak digemari kalangan menengah ke atas dan masyarakat perkotaan sehingga banyak ditemukan di pasar swalayan (Sirajuddin, 2010). Ada beberapa jenis jagung 
spesial yang memiliki nilai jual yang tinggi yang cocok dikembangkan di kawasan urban karena menjanjikan pendapatan yang lebih tinggi bagi petani jagung, salah satu contohnya adalah jagung manis (Mathukia, 2014)

Produksi jagung manis pada tahun 2014 mencapai 6.339,00 ton dengan luas panen $2.023,00$ ha atau, rata-rata sebasar 3,133 ton ha-1, sedangkan produksi nasional mencapai 18,54 ton dengan luas panen $3.786 .376,00$ ha atau rata-rata 4,899 ton per ha (Badan Pusat Statistik, 2014). Produktivitas jagung manis di Indonesia masih rendah (Masruhing et al., 2018) dengan rata-rata 5,18 ton ha-1, jauh dari potensi hasil yang dapat dicapai yaitu $15-20$ ton ha-1. Rendahnya produktivitas ini disebabkan antara lain pengelolaan yang masih tradisional dan kurangnya pemupukan (Pangaribuan et al., 2017).

Tanaman jagung, termasuk jagung manis banyak dibudidayakan pada lahan kering terutama pada tanah Ultisol. Menurut Bahri et al. (2016) kendala utama dalam eksploitasi pertanian di lahan kering adalah tingkat kesuburan tanah yang rendah. kelangkaan air, dan rendahnya $\mathrm{pH}$ tanah. Pupuk adalah material yang ditambahkan pada tanaman untuk mencukupi kebutuhan hara yang diperlukan tanaman sehingga mampu berproduksi dengan baik. Selanjutnya dikatakan oleh Utomo et al. (2016), pupuk yang umum ada dua jenis yaitu pupuk organik dan pupuk anorganik. Pupuk anorganik adalah pupuk sintetis yang dibuat oleh industri pabrik, sedangkan pupuk organik adalah pupuk kimia hasil fermentasi bahan-bahan alam.

Menurut Marsuni et al. (2013) pemberian bahan organik seperti pupuk hijau dari famili leguminoceae, dapat memperbaiki sifat fisik tanah, menyuplai bahan organik, menambah nitrogen dan fosfor serta dapat memperbaiki kehidupan jasad renik tanah. Pemberian pupuk organik diharapkan dapat meningkatkan kesuburan dan produktivitas tanah. Fungsi pupuk organik terhadap tanah dan tanaman yaitu memperbaiki struktur tanah, meningkatkan daya serap tanah terhadap air dan sebagai sumber unsur hara bagi tanaman. Pemberian bahan organik berupa pupuk organik dapat meningkatkan pertumbuhan dan hasil tanaman jagung manis, diantaranya penelitian Hasibuan (2013) yang mengaplikasikan limbah cair pabrik kelapa sawit dan Kresnatita et al (2013) dengan aplikasi kompos jerami dan pupuk kandang sapi. Selain memberikan nutrisi yang memadai melalui pemupukkan berimbang, untuk meningkatkan pertumbuhan dan produksi tanaman jagung manis yaitu dengan melakukan upaya efisiensi penerimaan radiasi aktif fotosintesis ini dengan memodifikasi luas total permukaan efektif daun melalui pemangkasan daun di bawah tongkol (Effendy et al., 2019). 
Nitrogen merupakan unsur hara yang bersifat mobil di dalam tumbuhan $\mathrm{N}$ akan dimolisasi dari jaringan tua ke jaringan muda, berfungsi sebagai kerangka yang berupa asam amonio, amida gusus amin, senyawa perantara (intermediary compounds) berupa protein, enzim, prekursor asam nukleat DNA, RNA dan Klorofil, di luar tanaman pada media tumbuh nitrogen berada dalam bentuk gas $\mathrm{NH}_{3}$ (amoniak) dapat diserap tanaman melalui daun, dalam bentuk senyawa anorganik $\mathrm{NH}_{4}$ (amonium) atau $\mathrm{NO}_{3}$ yang diserap tumbuhan melalui akar. Kecepatan absorpsi $\mathrm{N}$ oleh tumbuhan ditentukan oleh konsentrasi di media, tingkat keasaman dan kondisi media lainnya seperti kandungan udara dan air media serta bentuk senyawa N itu sendiri (Budianta dan Ristini, 2013). Nitrogen pada tanaman berfungsi dalam memperluas area daun sehingga dapat meningkatkan laju fotosintesis.

Peningkatan dosis pemupukan nitrogen dapat meningkatkan kandungan klorofil daun secara signifikan dan kanduangan protein biji pada tanaman jagung. Memegang peranan penting dalam berbagai proses fiiologis tanaman meningkatkan laju fotosintesis, Selanjutnya dinyatakan terdapat korelasi yang positif antara peningkatan kandungan klorofil daun dengan peningkatan kandungan protien biji pada tanaman jagung (Vanyine et al., 2012). Peningkatan dosis pupuk nitrogen memegang peranan kunci dalam berbagai proses fisiologis tanaman seperti peningkatan aktivitas fotosintesis, indeks luas daun (ILD) dan peningkatan LAD (Leaf Area Density). Penambahan suplai Nitrogen ke rizosfer tanaman jagung dapat memperbaiki komponen hasil pipilan jagung.

Turi Mini (TM) merupakan tanaman yang termasuk leguminosae. Pada umur 45 hari, tanaman ini memiliki tinggi yang relatif pendek yaitu sekitar $30-40 \mathrm{~cm}$ dengan lebar tajuk sebesar $20 \mathrm{~cm}$. Tanaman ini sangat potensial dijadikan pupuk hijau karena mampu hidup di lahan kering maupun lahan tergenang. Pada akar dan batangnya terdapat bintilbintil yang merupakan simbiosis dengan rhizobium sehingga dapat memfiksasi nitrogen dari udara. Tanaman ini mampu memfiksasi nitrogen 10 kali lebih besar dari tanaman legume lainnya. Kelebihan lain dari tanaman turi mini adalah dapat meningkatkan penyerapan nitrogen dan fosfor didalam tanah. Peningkatan efisiensi penyerapan $\mathrm{N}$ mencapai $25 \%$ dan terjadi peningkatan kandungan $\mathrm{N}$ tanah serta peningkatan penyerapan $\mathrm{P}$ yang berpengaruh positif terhadap pertumbuhan dan produksi tanaman (Hanson, 2005). Menurut Fahmi et al. (2010), hara Nitrogen dan Fosfor merupakan unsur hara yang dibutuhkan oleh tanaman dalam jumlah yang besar yang berfungsi dalam pembentukan klorofil, protoplasma, protein, dan asam inti. Nitrogen berperan 
dalam memacu pertumbuhan tanaman secara umum, terutama pada fase vegetatif (Hidayati dan Armaini, 2015).

Pemberian hara $\mathrm{N}$ yang tidak seimbang dengan kebutuhan tanaman baik jumlah maupun waktu pemberiannya akan menyebabkan kehilangan $\mathrm{N}$ dalam tanah, pertumbuhan tanaman yang tidak optimal, dan pada akhirnya menyebabkan rendahnya efisiensi penggunaan N (Suwardi dan Efendi, 2009). Penggunaan pupuk yang berlebihan, selain akan memperbesar biaya produksi juga akan merusak lingkungan akibat adanya emisi gas $\mathrm{N}_{2} \mathrm{O}$ pada proses amonifikasi, nitrifikasi, dan denitrifikasi (Wahid et al., 2003). Faktor tingkat kehilangan $\mathrm{N}$ dari pupuk Urea antara $60 \%$ sampai $80 \%$ pada lahan sawah, dan $40 \%$ sampai $60 \%$ pada lahan kering sehingga hanya sekitar $30 \%$ $50 \%$ yang dapat digunakan oleh tanaman. Rendahnya efisiensi ini disebabkan antara lain proses volatisasi yang menyebabkan kehilangan $\mathrm{N}$ sampai sebesar $70 \%$.

Menurut Koswara (1992) pupuk yang direkomendasikan untuk tanaman jagung manis adalah pupuk anorganik $435 \mathrm{~kg}$ urea ha ${ }^{-1}, 150 \mathrm{~kg} \mathrm{TSP} \mathrm{ha}^{-1}$, dan $150 \mathrm{~kg} \mathrm{KCl} \mathrm{ha-1}$. Sementara menurut Mathukia et al. (2014) berdasarkan hasil penelitiannya untuk mendapatkan hasil yang lebih tinggi, maka jagung manis ditanam dengan jarak tanam $45 \times 20 \mathrm{~cm}$ dan pemupukkan $120 \mathrm{~kg} \mathrm{~N}$ dan $60 \mathrm{~kg} \mathrm{P}_{2} \mathrm{O}_{5} \mathrm{ha}^{-1}$ sesuai kondisi agroklimat di Selatan Gujarat. Masih rendahnya produktivitas jagung manis dan pengelolaan yang masih tradisional khususnya penggunaan pupuk anorganik yang cukup tinggi, penulis mencoba menggunakan tanaman TM untuk mengurangi suplai nitrogen anorganik dalam upaya meningkatkan produktivitas tanaman jagung manis.

\section{BAHAN DAN METODE}

Penelitian ini dilaksanakan di Kelurahan Air Kuti, Kelurahan Taba Pingin, Kecamatan Lubuklinggau Selatan I, Kota Lubuklinggau, Provinsi Sumatera Selatan dengan ketinggian tempat 110 meter DPL dan dilakukan pada bulan April-Juni 2017.

Tanaman jagung manis yang digunakan yaitu varietas Bonanza. Dosis pupuk anjuran dalam penelitian ini mengacu pada (Koswara, 1992), yaitu $435 \mathrm{~kg} \mathrm{urea} \mathrm{ha-1}^{-1} 150$ kg TSP ha-1 dan $150 \mathrm{~kg} \mathrm{KCl} \mathrm{ha-1.} \mathrm{Polibag} \mathrm{yang} \mathrm{digunakan} \mathrm{berukuran} 40 \mathrm{~cm}$ (tinggi) x 30 cm (lebar). Tanah yang digunakan yaitu jenis tanah Ultisol. Penelitian ini menggunakan polibag yang disusun dalam rancangan acak lengkap kelompok (RALK) secara faktorial $4 \times 3$ dan diulang 3 kali. Faktor pertama yaitu kombinasi perlakuan dosis pupuk urea dan TM yang terdiri atas 4 macam, yaitu: $75 \%$ dosis anjuran $(326,25 \mathrm{~kg}$ urea ha-1) dan 1 batang TM; $50 \%$ dosis anjuran urea $(217,50 \mathrm{~kg}$ urea ha-1 $)$ dan 2 batang TM; $25 \%$ dosis anjuran urea $\left(108,75 \mathrm{~kg}\right.$ urea ha- $\left.^{-1}\right)$ dan $3 \mathrm{TM}$; dan $0 \%$ dosis anjuran urea (0 kg urea ha- 
${ }^{1}$ ) dan 4 batang TM. Faktor kedua yaitu perlakuan frekuensi aplikasi urea pada tanaman jagung manis yang terdiri atas 3 level, yaitu: 1 kali aplikasi (15 HST), 2 kali aplikasi (15 dan 30 HST), dan 3 kali aplikasi (15, 30, dan 45 HST). Tanaman jagung manis ditanam dalam polibag berukuran $40 \mathrm{~cm} \times 30 \mathrm{~cm}$ dan diisi tanah Ultisol $10 \mathrm{~kg}$. Tanaman TM ditanam pada polibag lain dan diisi tanah seberat $2 \mathrm{~kg}$ diletakan disamping polibag tanaman jagung. Penanaman jagung manis dilakukan satu minggu setelah pengisian polibag bersamaan dengan penanaman benih TM sesuai dengan perlakuan yaitu TM ditanam satu, dua, tiga, dan empat batang pada polibag kecil. Pada umur 40 HST tanaman TM dicabut, dicincang dengan panjang sekitar $2 \mathrm{~cm}$, kemudian dimasukan ke dalam polibag tanaman jagung dan ditimbun dengan menggunakan tanah dari bekas tanaman TM.

Parameter yang diamati meliputi: tinggi tanaman, jumlah daun, panjang tongkol tanpa kelobot, berat tongkol tanpa kelobot dan produksi tongkol tanpa kelobot per hektar. Untuk mengetahui pengaruh dari perlakuan terhadap parameter yang diamati digunakan analisis keragaman (analysis of variance) pada taraf $5 \%$. Untuk mengetahui perbedaan antara perlakuan digunakan uji beda nyata jujur (BNJ) pada level $5 \%$ (Paiman, 2016).

\section{HASIL ANALISIS DAN PEMBAHASAN}

Hasil analisis keragaman pada Tabel 1, terlihat bahwa kombinasi perlakuan urea dan TM berpengaruh nyata terhadap tinggi tanaman, jumlah daun, panjang tongkol berkelobot, berat tongkol berkelobot dan produksi tongkol berkelobot per hektar. Sementara frekuensi aplikasi pupuk berpengaruh nyata terhadap jumlah daun, berat tongkol tanpa kelobot dan berat tongkol tanpa kelobot ha-1. Interaksi perlakuan tidak berpengaruh nyata terhadap semua parameter yang diamati.

Tabel 1. Hasil analisis keragaman terhadap semua parameter yang diamati

\begin{tabular}{llrrrl}
\hline \multirow{2}{*}{ No } & \multirow{2}{*}{ Peubah yang diamati } & \multicolumn{3}{c}{ Perlakuan } & \multirow{2}{*}{ KK $(\%)$} \\
\cline { 3 - 4 } 1. & Tinggi Tanaman $(\mathrm{cm})$ & $\mathrm{P}$ & $\mathrm{F}$ & $\mathrm{I}$ & \\
2. & Jumlah Daun (helai) & $39,40 * 1^{*}$ & $0,13^{\mathrm{tn}}$ & $0,16 \mathrm{tn}$ & 4,36 \\
3. & Panjang tongkol tanpa kelobot $(\mathrm{cm})$ & $3,69 *$ & $1,78 \mathrm{tn}$ & 5,65 \\
4. & Berat tongkol tanpa kelobot $(\mathrm{g})$ & $0,35 \mathrm{tn}$ & 7,04 \\
5. & Produksi tongkol tanpa kelobot ton $\mathrm{ha}^{-1}$ & $3,45^{*}$ & $4,16 *$ & $0,24 \mathrm{tn}$ & 9,13 \\
& & $4,16^{*}$ & $0,24 \mathrm{tn}$ & 9,13
\end{tabular}

Keterangan: $\mathrm{P}=$ Kombinasi perlakuan dosis pupuk urea dan $\mathrm{TM}, \mathrm{F}=$ Perlakuan frekuensi aplikasi urea, I = Interaksi $\mathrm{P} \times \mathrm{F},{ }^{*}=$ berpengaruh nyata pada taraf nyata $5 \%$, tn $=$ Tidak berpengaruh nyata pada taraf nyata $5 \%$, dan $\mathrm{KK}=$ Koefisien keragaman $(\%)$. 
Table 2. Pengaruh kombinasi urea dan TM serta frekuensi aplikasi urea terhadap tinggi tanaman, jumlah daun, panjang dan bobot tongkol serta hasil ha-1

\begin{tabular}{|c|c|c|c|c|c|}
\hline \multirow[t]{2}{*}{ Perlakuan } & \multicolumn{5}{|c|}{ Parameters pengamatan } \\
\hline & $\begin{array}{l}\text { Tinggi } \\
\text { tanaman } \\
(\mathrm{cm})\end{array}$ & $\begin{array}{c}\text { Jumlah } \\
\text { daun (leaf) }\end{array}$ & $\begin{array}{c}\text { Panjang } \\
\text { tongkol } \\
(\mathrm{cm})\end{array}$ & $\begin{array}{c}\text { Bobot per } \\
\text { tonggkol } \\
\text { (g) }\end{array}$ & $\begin{array}{l}\text { Bobot } \\
\text { tongkol } \\
\text { (ton/ha) }\end{array}$ \\
\hline \multicolumn{6}{|c|}{ Kombinasi dosis pupuk urea dan TM (P) } \\
\hline $326.25+1 \mathrm{TM}$ & $137,33 \mathrm{~b}$ & $12,00 \mathrm{~b}$ & 23,41 a & $224,07 a b$ & $12,55 a b$ \\
\hline $217.50+2 \mathrm{TM}$ & $142,86 b$ & $12,14 \quad b$ & $25,22 a b$ & $241,82 \quad b$ & $13,54 \mathrm{~b}$ \\
\hline $108.75+3 \mathrm{TM}$ & $143,07 \quad b$ & $12,80 \mathrm{~b}$ & 26,00 b & $224,07 a b$ & 12,08 \\
\hline $0+4 \mathrm{TM}$ & 126,33 a & 9,67 a & $24,36 a b$ & 210,81 a & 11,81 a \\
\hline BNJ at $5 \%$ & 7,09 & 0,78 & 2,06 & 24,32 & 1,36 \\
\hline \multicolumn{6}{|c|}{ Frekuensi aplikasi urea (F) } \\
\hline $1 \mathrm{x}$ & $136,94 p$ & $11,09 \mathrm{p}$ & $42,67 \mathrm{p}$ & $217,17 p$ & $12,16 p$ \\
\hline $2 x$ & $137,14 p$ & $11,22 \mathrm{p}$ & $24,25 \mathrm{p}$ & $219,31 p$ & $12,28 p$ \\
\hline $3 x$ & $138,11 p$ & $12,56 \mathrm{q}$ & $25,32 p$ & $209,12 p$ & $13,64 \mathrm{q}$ \\
\hline BNJ at $5 \%$ & - & 0,74 & - & - & 1,29 \\
\hline Interaksi P x F & $(-)$ & $(-)$ & $(-)$ & $(-)$ & $(-)$ \\
\hline
\end{tabular}

Hasil uji BNJ pada taraf $5 \%$ dari pengaruh perlakuan kombinasi urea dan TM serta frekuensi aplikasi urea terhadap tinggi tanaman, jumlah daun, panjang dan bobot tongkol serta hasil ha-1 dapat dilihat pada Tabel 2 diatas.

\section{Komponen Pertumbuhan}

Berdasarkan Tabel 2 menunjukkan bahwa perlakuan kombinasi $25 \%$ dosis anjuran urea $\left(108,75 \mathrm{~kg}_{\text {urea ha-1 }}{ }^{-1}\right)$ dan 3 TM menghasilkan tanaman tertinggi yaitu 143,07 cm dan jumlah daun terbanyak yaitu 12,80 helai. Hikmawati (2014) mengemukakan pemberian nitrogen dapat meningkatkan kandunagan butir hijau daun yang mempunyai peranan sangat penting dalam proses fotosintesis dan mempercepat pertunbuhan tanaman. Semakin besar pemberian $\mathrm{N}$ menyebabkan tinggi dan bobot kering tanaman semakin besar. Hal ini berhubungan dengan kecukupan hara yang akan diserap oleh tanaman. Nitrogen berfungsi untuk merangsang pertumbuhan, memperbesar bulir, dan meningkatkan kandungan protein pada tanaman serelia, mengatur penggunaan fosfor, kalium, dan penyusun lainnya. Nitrogen berperan dalam merangsang pertumbuhan secara keseluruhan dan pembentukan kehijauan daun yang sangat berguna dalam proses fotosintesis. Selain itu, nitrogen berperan dalam membentuk protein, lemak, dan berbagai persenyawaan organik lainnya.

Perlakuan $50 \%$ dosis anjuran urea dan 2 TM maupun 25\% dosis anjuran urea dan 3 TM merupkan perlakuan terbaik. Diduga ketersediaan nitrogen di dalam media 
tumbuh dapat didukung oleh adanya suplai nitrogen dari tanaman TM yang banyak mengandung bintil rhyzobium. Pertumbuhan tinggi tanaman dan jumlah daun yang lebih besar dibandingkan dengan perlakuan $75 \%$ dosis anjuran urea dan 1 TM maupun $0 \%$ dosis anjuran urea dan 4 TM. Tingginya nitrogen pada perlakuan ini akan berakibat pada peningkatan sintesis asam amino, protein dan substrat pemacu pertumbuhan, yang akan mendorong aktivitas jaringan meristimatik melakukan pembelahan dan perkembangan sel. Terpenuhinya kebutuhan nitrogen ini diduga akan meningkatkan tinggi tanaman dan jumlah daun. Hal ini sesuai dengan yang dikemukakan oleh (Mathukia et al., 2014). Menurut Saraswati dan Matoh (1993), TM mempunyai kemampuan untuk tumbuh di lahan masam, salin, dan kondisi tergenang maupun kering. TM termasuk tanaman kacang-kacang yang mampu membentuk bintil akar dan bintil pada batang, bersimbiosis dengan Azorhizobium caulinodans yang dapat menambat $\mathrm{N}$ dari udara, sehingga dapat dimanfaatkan sebagai pupuk hijau. Hasil penelitian tampak bahwa TM paling toleran pada $\mathrm{pH}$ rendah, $S$. cannabina toleran terhadap kondisi salin dan tergenang. TM mampu menghasilkan 16,8 ton ha ${ }^{-1}$ bahan kering dan $426 \mathrm{~kg} \mathrm{~N} \mathrm{ha}^{-1}$.

Hasil analisis keragaman perlakuan frekuensi pemberian pupuk urea berpengaruh nyata terhadap jumlah daun. Perlakuan frekuensi aplikasi urea tidak berpengaruh nyata terhadap tinggi tanaman, tetapi berpengaruh nyata terhadap jumlah daun. Aplikasi urea tiga kali memberikan jumlah daun terbanyak yaitu 12,56 helai, dan berbeda nyata dengan aplikasi urea 2 dan 1 kali. Hal ini diduga berkaitan dengan sifat dari urea yang mudah menguap dan tercuci oleh air.

\section{Komponen Hasil}

Pengaruh perlakuan terhadap komponen produksi (Tabel 2) menunjukkan bahwa kombinasi perlakuan 25\% urea anjuran dan 3 batang TM menghasilkan panjang tongkol terpanjang $26,0 \mathrm{~cm}$ dan berbeda nyata dengan perlakuan $75 \%$ urea anjuran dan 1 batang TM. Berat tongkol tanpa kelobot pada Tabel 2 menunjukkan bahwa kombinasi perlakuan $50 \%$ urea anjuran dan 2 batang TM menghasilkan berat tongkol terberat yaitu $241,82 \mathrm{~g} \mathrm{tongkol}^{-1}$ dan berbeda nyata dengan perlakuan $0 \%$ urea anjuran dan 4 batang TM. Perlakuan 50\% urea anjuran dan 2 batang TM memberikan hasil tertinggi produksi tongkol yaitu 13,54 ton ha-1. Perlakuan frekuensi aplikasi 3 kali menghasilkan tongkol terberat yaitu 13,39 ton ha-1. Perlakuan $50 \%$ urea anjuran dan 2 batang TM memberikan hasil tertinggi yaitu 13,54 ton ha-1 dan berbeda nyata dengan $25 \%$ urea anjuran dan 3 batang TM, dan $0 \%$ urea anjuran dan 4 batang TM, namun tidak berbeda dengan $75 \%$ urea anjuran dan 1 batang TM. TM memberikan harapan untuk 
dapat dimanfaatkan sebagai tanaman yang mampu mengurangi penggunaan pupuk anorganik (urea) untuk memenuhi kebutuhan nitrogen tanaman.

Kombinasi perlakuan urea $50 \%$ dan $25 \%$ dari dosis anjuran yang ditambahkan 2 atau 3 batang tanaman TM mampu mengurangi penggunaan urea anorganik. Hal ini diduga karena pupuk $\mathrm{N}$ yang diberikan melalui aplikasi urea dan suplai nitrogen yang berasal dari tanaman TM ini mampu memenuhi kebutuhan tanaman untuk pertumbuhan serta meningkatkan produksi tanaman jagung manis, disamping efek bahan organik yang secara teoritis berdampak positif bagi sifat-sifat tanah. Pemberian pupuk urea yang dilakukan berulang akan menambah ketersediaan unsur hara $\mathrm{N}$ yang dibutuhkan tanaman, sehingga membantu dalam proses fotosintesis yang berdampak pada pertumbuhan dan produksi jagung manis. Menurut Sukarto et al. (2011) bahwa laju fotosintesis harus didukung oleh ketersediaan nutrisi yang cukup. Perkembangan jaringan tanaman sangat ditentukan oleh ketersediaan unsur hara terutama unsur nitrogen. Ketersediaan nitrogen yang cukup menyebabkan tanaman akan membentuk bagian-bagian vegetatif dengan cepat melalui pembelahan sel, perpanjangan, dan pembesaran sel serta membentuk dinding sel baru dan protoplasma.

Sementara frekuensi aplikasi urea tidak menunjukkan perbedaan yang nyata. Frekuensi aplikasi urea tidak memberikan pengaruh nyata terhadap berat tongkol tanpa kelobot. Frekuensi aplikasi 3 kali memberikan hasil tertinggi 13,64 ton ha-1 dan berbeda nyata dengan frekuensi aplikasi 2 dan 1 kali. Frekuensi aplikasi urea pada penelitian ini masih sejalan dengan teori aplikasi pupuk urea yang menyatakan bahwa semakin sering aplikasi pupuk urea dapat meningkatkan efisiensi penyerapan unsur nitrogen yang berasal dari pupuk urea, sejalan dengan pendapat Damanik et al. (2011) mengatakan keberhasilan pemupukan juga ditentukan oleh faktor waktu pemupukan. Waktu pemberian haruslah tepat, pemberian pupuk yang terlalu awal akan membuat pupuk cepat hilang karena pencucian dan penguapan urea sehingga tidak terserap oleh tanaman, jadi pupuk harus diberikan sehingga saat tanaman membutuhkan unsur hara tersebut tersedia bagi tanaman. Hal ini sejalan dengan Hairiah et al. (2000) yang mengatakan pupuk $\mathrm{N}$ mudah teroksidasi, sehingga cepat menguap atau tercuci sebelum tanaman menyerap seluruhnya, hanya sekitar 30\% - 50\% yang dapat digunakan oleh tanaman. Rendahnya efisiensi ini disebabkan antara lain proses volatisasi yang menyebabkan kehilangan $\mathrm{N}$ sampai sebesar $70 \%$.

Perlakuan frekuensi pupuk urea 1 kali aplikasi memberikan nilai terendah pada semua parameter yang diamati. Hal ini diduga aplikasi urea 1 kali tidak mampu mencukupi ketersediaan $\mathrm{N}$ yang dibutuhkan tanaman, selain itu pertumbuhan tanaman 
juga dipengaruhi oleh faktor genetik dan lingkungan. Siregar dan Marzuki (2011) unsur $\mathrm{N}$ yang dapat diserap tanaman yang bersumber dari urea hanya $30 \%$ saja. Faktor lingkungan dapat melalui pemberian nitrogen dalam tanah, karena tanaman yang kekurangan nitrogen akan mempengaruhi kandungan klorofil pada daun sehingga mempengaruhi laju fotosintesis. Hasil analisis keragaman menunjukkan bahwa interaksi perlakuan kombinasi pemberian urea + TM dan frekuensi aplikasi pupuk urea tidak berpengaruh nyata terhadap semua parameter yang diamati. Hal ini diduga interaksi antar perlakuan dipengaruhi oleh lingkungan dan cuaca. Damanik et al. (2011) mengatakan keberhasilan pemupukan juga ditentukan oleh faktor waktu pemupukan. Waktu pemberian haruslah tepat, misalnya pemberian pupuk yang terlalu awal akan membuat pupuk cepat hilang sehingga tidak terserap oleh tanaman, jadi pupuk harus diberikan sehingga saat tanaman membutuhkan unsur hara tersebut tersedia bagi tanaman.

\section{KESIMPULAN}

Berdasarkan analisis hasil dan pembahasan, maka dapat diambil kesimpulan bahwa pemberian pupuk urea $25 \%$ dari dosis anjuran (435 kg urea ha-1) yang dikombinasikan dengan 3 batang tanaman TM menghasilkan pertumbuhan dan hasil tanaman jagung manis yang terbaik. Perlakuan frekuensi aplikasi urea sebanyak 3 kali menghasilkan pertumbuhan dan hasil tanaman jagung manis yang terbaik.

Berdasarkan hasil penelitian ini disarakan bahwa perlu dilakukan penelitian lanjutan mengenai pemanfaatan tanaman TM sebagai upaya pengurangan penggunaan pupuk $\mathrm{N}$ yang bersumber dari urea anorganik dengan menambahkan tanaman TM sebagai substitusi urea pada berbagai umur tanaman TM.

\section{DAFTAR PUSTAKA}

Bahri, S., Budianta, D., dan Munandar. 2016. Perubahan Karakteristik Beberapa Sifat Kimia Tanah dengan Pemberian Biochar dan Pupuk Kandang Ayam pada Tanah Ultisol. Jurnal Klorofil, 11(2) : 77-84.

Badan Pusat Statistik, 2014. Luas. panen, produktivitas, dan produksi jagung manis menurut provinsi. http://www.bps.go.id. Diakses tanggal 20 Agustus 2019.

Damanik, M.M.B., Bacthiar E.H., Fauzi, Sarifuddin, dan Hamidah H., 2011.Kesuburan Tanah dan Pemupukan USU Press, Medan. Hal 262

Effendy, I., Gribaldi dan Benny, A.J. 2019. Aplikasi Sabut Kelapa dan Pupuk Bokasi Kotoran Ayam terhadap Pertumbuhan Bibit Sawit di Pre-Nurseri. Jurnal Agrotek Tropika, 7(2): 405-412. 
Fahrurrozi, Zainal Muktamar, Dwatmadji, N. Setyowati, S. Sudjatmiko, dan M. Chozin. 2016. Growth and Yield Responses of Three Sweet Corn (Zea mays L. var. Saccharata) Varieties to Local-based Liquid Organic Fertilizer. International Journal on advanced Science Engeenering Information Technology . 6 (3): 319323.

Fahmi, A., Syamsudin, S. N. H. Utami, dan B. Radjagukguk. 2010.Pengaruhinteraksi hara Nitrogen dan Fosfor terhadap pertumbuhan tanaman jagung (Zea mays L.) pada tanah regosol dan latosol.Berita Biologi 10(3) : 297-304

Hairiah, K, Widianto, S.R. Otami, D. Suprayogo, Sunaryo, S.M. Sitompul, B. Lusiama, R.Mulia, M.V. Noordnizk dan G. Cadish. 2000. Pengelolaan Tanah Masam Secara Biologi. Universitas Lampung, Lampung.

Hanson, J. 2005. Sesbania rostrata. Tropical Forages. http://www.tropicalforage. info/index.htm.

Hasibuan, S. 2013. Tanggap Pertumbuhan dan Produksi Tanaman Jagung Manis(Zea mays saccharataSturt. L.) terhadap Pemberian Pupuk Limbah Cair Pabrik Kelapa Sawit dan PupukTSP. J.Penelitian Pertanian BERNAS. 8 (3) : 38-42.

Hidayati, E.,dan Armaini. 2015. Aplikasi limbah cair biogas sebagai pupukorganik pada tanaman jagung manis (Zea maysvar.saccharataSturt).JOM Faperta1(2) :1-14.

Hikmawati, M. 2014. Pengaruh varietas dan penggunaan dosis pupuk terhadap produksi jagung (Zea mays L.). Jurnal Media Soerjo.14(1): 70-84.

Jurnaha, Made, U., dan Madauna, I. 2017. Pertumbuhan dan Hasil Tanaman Jagung (Zea mays var. saccharata) pada Berbagai Dosis Pupuk Organik. E-J. Agrotekbis, 5(3): 324-328.

Koswara, J. 1992. Pengaruh Dosis Pupuk dan Waktu Pemberian Pupuk N, P dan K terhadap Produksi dan Pertumbuhan Jagung Manis. Seleksi Dermaga 2 (502). Pert Indonesia, 2(1): 1-6.

Kresnatita, S., Koesrihati dan Santoso M. 2013. Pengaruh Rabuk Organik terhadap Pertumbuhan dan Hasil Tanaman Jagung Manis.Indonesian Green Technology Journal.2 (1) : 2338-1787

Marschner, H. 1986. Mineral Nutrition of Higher Plants. Institute of Plant Nutrition Univ. Hohenheim. Fed. Rep. of Jerman.

Marsuni, Z., St. Subaedah, dan Koes, F. 2013. Keragaan Pertumbuhan Jagung dengan Pemberian Pupuk Hijau Disertai Pemupukan $N$ dan $P$. Seminar Nasional Serealia, 2013.

Masruhing, B., Hasrianti dan A. Abdullah. 2018. Pertumbuhan dan Produksi Tanaman Jagung Manis (zea mays saccharata sturt) pada berbagai dosis pupuk kandang dan pupuk organik cair. Jurnal Agrominansia. 3 (2) : 141-149

Mathukia, R.K., Chaudhary, R.P., Shivran, A., and Bhosale, N. 2014. Response of Rabbi Sweet Corn to Plant Geometry and Fertilizer. Current Biotica, 7(4): 294-298.

Nuryadin, A.K., E. Suprapti, A. Budiyono. 2016. Pengaruh Jarak Tanam dan Dosis Pupuk NPK terhadap Pertumbuhan dan Hasil Jagung Manis. Agrineca. (16)2: 1223. 
Paiman. 2016. Perancangan Percobaan untuk Pertanian. UPY Press. Yogyakarta. 426 hal.

Pangaribuan, D.H., Ginting, Y.C., Saputra, L.P., dan Fitri, H. 2017. Aplikasi Pupuk Organik Cair dan Pupuk Anorganik terhadap Pertumbuhan, Produksi, dan Kualitas Pascapanen Jagung Manis (Zea mays var. Saccharata Sturt.). J. Hort. Indonesia, 8(1): 59-67.

Saraswati, R., dan Matoh, T. 1993. Toleransi terhadap Cekaman Edafik dan Penambatan Nitrogen Genus Sesbania. Penelitian Pertanian, 13(1): 36-40.

Siregar, A. dan I. Marzuki. 2011. Effisiensi Pemupukan Urea terhadap Serapan N dan Peningkatan Produksi Pasi Sawah (Oryza sativa.L). Jurnal Budidaya Pertanian. 7 (2):107-112.

Sirajuddin, M. 2010. Komponen Hasil dan Kadar Gula Jagung Manis (Zea Mays Saccharata Sturt) terhadap Pemberian Nitrogen dan Zat Tumbuh Hidrasil. Penelitian Mandiri. Fakultas Pertanian. UNTAD. Palu.

Sukarto, W.H. Utomo, Z. Kusuma, dan W.H. Nugroho. 2011. Soil fertility status, nutrient uptake, and maize (Zea mays L.) yield following biochar and cattle manure application on sandy soil of Lombok, Indonesia. Journal of Trop. Agri., 49, 4752.

Suwardi, dan Efendi, R. 2009. Efisiensi Penggunaan Pupuk N pada Jagung Komposit Menggunakan Bagan Warna Daun. Balai Penelitian Tanaman Serelia. 115 hal.

Utomo, M., T. Sabrina, Sudarsono, J. Lumbanraja, B. Rusman, Wawan. 2016. IImu Tanah: Dasar-dasar dan Pengelolaan. Kencana, Prenada Media Group. Jakarta. 433 hal.

Vanyine, A.S., B. Toth, J. Nagy. 2012. Effect of nitrogen dose on chloropyyll cocentration, yield and protein content of different genotype maize hibrids in Hungary. African Journal of Agricultural Research. 16:2546-2552.

Wahid, A.S. 2003. Peningkatan Efisiensi Pupuk Nitrogen Pada Padi Sawah Dengan Metode Bagan Warna Daun. Jurnal Libang Pertanian. P. 157 